\title{
Article \\ Light Shelf Development Using Folding Technology and Photovoltaic Modules to Increase Energy Efficiency in Building
}

\author{
Heangwoo Lee ${ }^{1}$, , Sowon Han ${ }^{1}$ and Janghoo Seo ${ }^{2, *}$ \\ 1 College of Design, Sangmyung University, Cheonan-si 31066, Korea; 2hw@smu.ac.kr (H.L.); \\ hkghkdfyd123@naver.com (S.H.) \\ 2 School of Architecture, Kookmin University, 77, Jeongneung-ro, Seongbuk-gu, Seoul 02707, Korea \\ * Correspondence: seojh@kookmin.ac.kr; Tel.: +82-02-910-4593
}

check for

updates

Citation: Lee, H.; Han, S.; Seo, J.

Light Shelf Development Using

Folding Technology and Photovoltaic

Modules to Increase Energy

Efficiency in Building. Buildings 2022,

12, 81. https://doi.org/10.3390/

buildings 12010081

Academic Editors: Zhenjun Ma,

Alessandro Cannavale and

Jianhui $\mathrm{Hu}$

Received: 29 November 2021

Accepted: 13 January 2022

Published: 15 January 2022

Publisher's Note: MDPI stays neutral with regard to jurisdictional claims in published maps and institutional affiliations.

Copyright: (C) 2022 by the authors. Licensee MDPI, Basel, Switzerland. This article is an open access article distributed under the terms and conditions of the Creative Commons Attribution (CC BY) license (https:// creativecommons.org/licenses/by/ $4.0 /)$.

\begin{abstract}
Some recent research in the area of light shelves has been focused on applying photovoltaic modules to light shelves to save building energy. However, due to the modules installed on the light shelf reflectors, most such light shelves have failed to improve both daylighting and generation efficiency. This study proposes a folding technology to improve light shelves' daylighting and generation efficiency that uses photovoltaic modules and validates their performance using a testbed. The major obtained findings are as follows: (1) The proposed folding technology has a structure in which reflectors and photovoltaic modules fold alternately by modularizing the light shelf. The reflector and photovoltaic modules are controlled by adjusting the degree of folding. (2) Because light shelf angles for improving daylighting and generation differed depending on the application of the photovoltaic module, the optimal light shelf specifications differed. (3) Compared to previous light shelf technologies, the light shelf with folding technology and a photovoltaic module reduced energy use by $31.3 \%$ to $38.2 \%$. This demonstrates the efficacy of the proposed system. (4) Applying a photovoltaic module can lower the indoor uniformity ratio, which means that the daylighting performance of the light shelf is degraded due to the reduction of the area occupied by the reflector.
\end{abstract}

Keywords: light shelf; photovoltaic module; folding technology; performance evaluation; energy efficiency

\section{Introduction}

Recently, research on daylighting and shading systems such as light shelves, light pipes, blinds, louvers, and awnings has been increasing to reduce the consumption of lighting energy in indoor spaces and create a comfortable indoor light environment [1-5]. Among these systems, a light shelf is a type of reflector that contributes to lighting energy savings by reflecting and introducing natural light deep into a room [6-9]. It can also increase daylighting efficiency by responding to external environmental factors like solar altitude [10] by controlling the angle of the reflector. Several studies on light shelves have been conducted, indicating that their efficiency is widely recognized. Recent studies on light shelves [11,12] have discovered that applying photovoltaic modules that convert sunlight into electricity to the light shelf can increase building energy savings. However, most of the approaches studied [12] have involved the application of photovoltaic modules to part of the light shelf reflector. When photovoltaic modules are attached to the light shelf reflector, the two components end up having the same angle, which is not suitable for maximizing daylighting and generation performance at the same time. This is because light shelves and photovoltaic modules require different angles to maximize daylighting and generation performance.

As a result, this study proposes and validates a method for simultaneously improving the daylighting and generation efficiency of light shelves that use photovoltaic modules using a full-scale testbed. 


\subsection{The Light Shelves Concept and Operation Technologies}

As shown in Figure 1, a light shelf is one of the most prevailing daylighting systems installed on windows (inside or outside) that saves lighting energy by introducing natural light inside a building (room) by reflecting sunlight through the light shelf reflector [8-10]. Light shelves can also help to solve indoor illuminance imbalances caused by differences in illuminance between areas near and far from windows by preventing entry of some of the excessive natural light from the window. On the other hand, it can introduce natural light deeper into an indoor space by reflecting natural light from the ceiling, and reflector, so reflections from the reflector and ceiling surface are typically considered. The variables such as angle, height, reflectance, and width of light shelves determine its performance. Similarly, the light shelf angle is a primary variable to respond to external environmental factors such as the solar altitude, as shown in Figure 1 [10,12].

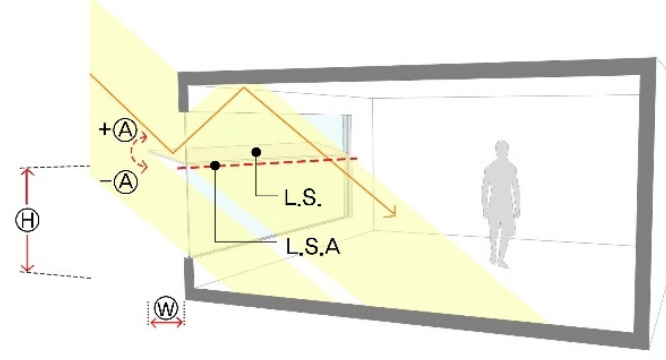

L.S. : Light shelf L.S.A : Light shelf angle control rotation shaft (W): Width +(A): +Angle -(A): -Angle (H): Height

(a)

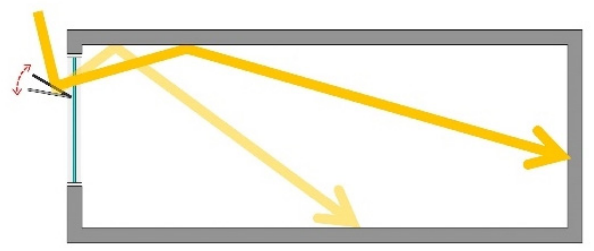

(b)

Figure 1. Light shelf concept and operation: (a) Concept and variables, (b) Inflow of the natural light by manipulating angle of the light shelf.

Several studies have been conducted on light shelves to improve their daylighting performance, and some of these are listed in Table 1. Researchers have attempted to enhance the light shelf reflectors' shape and also used multiple building envelope component technologies such as blinds and awnings to improve light shelf daylighting performance [8,9,11-21]. Some recent studies, in particular, have concentrated on movable light shelves using information technologies such as user recognition and location awareness $[10,22]$. However, these studies controlled the light shelf angle using a rotating shaft (see Figure 1). Previous studies on light shelves with photovoltaic modules $[11,12]$ have attached photovoltaic modules to the front or part of the light shelf reflector. Installing photovoltaic modules on the part of the light shelf reflector was more advantageous in saving building energy than applying them to the front due to enabling daylighting and concentrating light at the same time [12]. Previous studies that used photovoltaic modules on light shelves [12] encountered difficulties in maximizing daylighting and generation at the same time because the reflector that reflects natural light and the photovoltaic module that concentrates light maintain the same angle. 
Table 1. Previous studies on light shelves.

\begin{tabular}{|c|c|c|c|}
\hline Author & Purpose & $\begin{array}{l}\text { Photovoltaic Module } \\
\text { Application }\end{array}$ & $\begin{array}{c}\text { Consideration of } \\
\text { Operation Technologies }\end{array}$ \\
\hline Lim and Heng [8] & $\begin{array}{l}\text { Proposal and performance } \\
\text { evaluation of dynamic internal light } \\
\text { shelf in high-rise office buildings }\end{array}$ & \multirow{13}{*}{ No } & \\
\hline Claros and Soler [13] & $\begin{array}{l}\text { Performance evaluation according } \\
\text { to light shelf reflectance }\end{array}$ & & $\begin{array}{l}\text { Not considered } \\
\text { (Fixed light shelf) }\end{array}$ \\
\hline Warrier and Raphael [14] & $\begin{array}{l}\text { Indoor visual comfort analysis } \\
\text { according to the presence of } \\
\text { light shelves }\end{array}$ & & \\
\hline Lee [9] & $\begin{array}{l}\text { Performance evaluation of } \\
\text { perforated light shelves in response } \\
\text { to external wind pressure }\end{array}$ & & \multirow{9}{*}{$\begin{array}{l}\text { Light shelf angle control by } \\
\text { a single rotating shaft }\end{array}$} \\
\hline Lee et al. [15] & $\begin{array}{l}\text { Performance evaluation of light } \\
\text { shelves with diffusion sheets }\end{array}$ & & \\
\hline Lee and Seo [16] & $\begin{array}{l}\text { Proposal of a prism sheet } \\
\text { application method for improving } \\
\text { light shelf performance }\end{array}$ & & \\
\hline Mangkuto et al. [17] & $\begin{array}{l}\text { Parametric design study of light } \\
\text { shelves for application to } \\
\text { hospital buildings }\end{array}$ & & \\
\hline Lee et al. [18] & $\begin{array}{l}\text { Performance evaluation of light } \\
\text { shelves by applying curvature }\end{array}$ & & \\
\hline Meresi [19] & $\begin{array}{l}\text { Evaluation of the light shelf } \\
\text { performance based on the } \\
\text { application of the external blinds }\end{array}$ & & \\
\hline Lee [20] & $\begin{array}{l}\text { Development and performance } \\
\text { evaluation of a light shelf that can } \\
\text { change the reflectivity }\end{array}$ & & \\
\hline $\begin{array}{l}\text { AmirEbrahimi-Moghadam } \\
\text { et al. [21] }\end{array}$ & $\begin{array}{l}\text { Performance evaluation of interior } \\
\text { light shelves }\end{array}$ & & \\
\hline Kim et al. [10] & $\begin{array}{l}\text { Development and performance } \\
\text { evaluation of light shelves based on } \\
\text { user-awareness technology }\end{array}$ & & \\
\hline Lee et al. [22] & $\begin{array}{l}\text { Performance evaluation of light } \\
\text { shelves with } \\
\text { location-awareness technology }\end{array}$ & & $\begin{array}{l}\text { Light shelf and light shelf } \\
\text { angle control by multiple } \\
\text { rotating shafts }\end{array}$ \\
\hline Hwang et al. [11] & $\begin{array}{c}\text { Performance evaluation of } \\
\text { photovoltaic-integrated light } \\
\text { shelf systems }\end{array}$ & \multirow{2}{*}{ Yes } & $\begin{array}{l}\text { Not considered } \\
\text { (Fixed light shelf) }\end{array}$ \\
\hline Lee [12] & $\begin{array}{l}\text { Performance evaluation of light } \\
\text { shelves according to photovoltaic } \\
\text { module attachment ratio }\end{array}$ & & $\begin{array}{l}\text { Light shelf angle control by } \\
\text { a single rotating shaft }\end{array}$ \\
\hline
\end{tabular}

\subsection{Concept and Power Generation Principle of Photovoltaic Modules}

As shown in Figure 2, a photovoltaic module is a structure of photovoltaic cells connected by a ribbon to generate the required energy [23,24]. A photovoltaic cell is the smallest unit that converts solar energy into electrical energy and has p-n semiconductor junction structures. When photovoltaic cells absorb photons from the outside, electrons and holes are generated inside the photovoltaic cells, as shown in Figure 2. These electrons and holes migrate to n-type and p-type semiconductors. This movement drives the load of the photovoltaic cells, generating electrical energy. The generation process allows the 
photovoltaic cell to transform the solar energy into electrical energy. Temperature is a factor that has a significant impact on the power generation efficiency of photovoltaic cells. This efficiency decreases as the temperature rises [25-30]. In addition, the photovoltaic cells should be perpendicular to the sun to increase power generation efficiency, and the efficiency decreases as the sunlight deviates from a vertical angle [31-33].

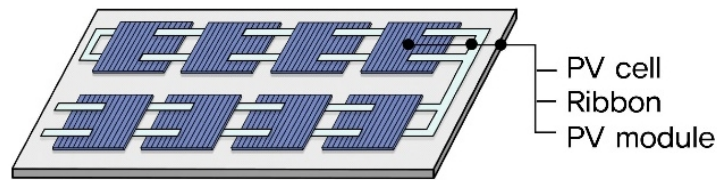

a)

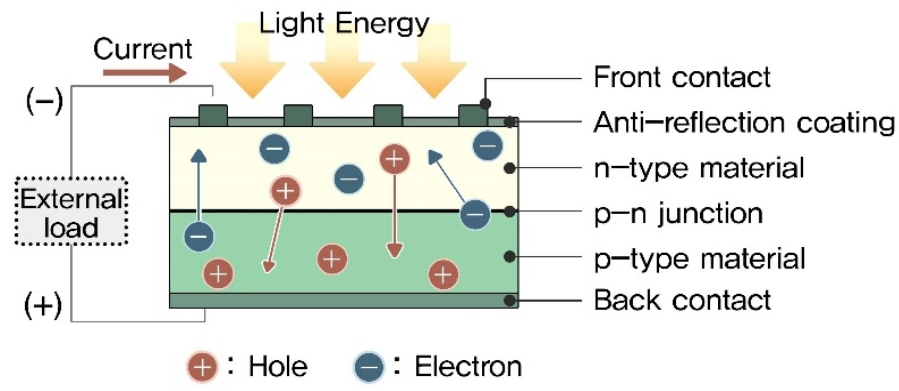

(b)

Figure 2. Photovoltaic module concept and power generation principle of photovoltaic cells: (a) Photovoltaic module concept, (b) Principle of the power generation.

\subsection{Indoor Illuminance Standards for Lighting Control}

Maintaining optimal indoor illuminance can increase the efficiency of visual work by creating a comfortable light environment for occupants and saving building energy by preventing unnecessary lighting control [34]. The optimal range of indoor illuminance is determined by the type of workplace or the level of visual work. This study considered the optimal illuminance standards in the United States [35], Japan [36], and Korea [37] based on the grade of visual work, as shown in Table 2. The illuminance standards in these countries, however, differ. As a result, this study established the optimal indoor illuminance standard at $500 \mathrm{~lx}$ based on the intersection for general visual work in the United States, Japan, and Korea and used this standard to assess the performance of light shelves.

Table 2. Indoor illuminance standards for visual work in the US, Korea, and Japan.

\begin{tabular}{|c|c|c|c|}
\hline \multirow[b]{2}{*}{ Country } & \multirow[b]{2}{*}{$\begin{array}{c}\text { Optimal Indoor } \\
\text { Illuminance Standards }\end{array}$} & \multirow[b]{2}{*}{ Task Grade } & \multirow{2}{*}{$\begin{array}{c}\text { Illuminance Range (lx) } \\
\text { Minimum-Standard- } \\
\text { Maximum }\end{array}$} \\
\hline & & & \\
\hline \multirow{2}{*}{ USA } & \multirow{2}{*}{ IES [35] } & General & $500-750-1000$ \\
\hline & & Simple & $200-300-500$ \\
\hline \multirow{2}{*}{ Japan } & \multirow{2}{*}{ JIS Z 9110 [36] } & General & $300-500-600$ \\
\hline & & Simple & $150-200-300$ \\
\hline \multirow{2}{*}{ Republic of Korea } & \multirow{2}{*}{ KS A 3011 [37] } & General & $300-400-600$ \\
\hline & & Simple & $150-200-300$ \\
\hline
\end{tabular}

\section{Methods}

\subsection{Proposal of Light Shelf That Applies Folding Technology and Photovoltaic Modules}

This study adopted folding technology to propose a way to simultaneously improve the daylighting and generation performance of light shelves that apply photovoltaic modules, and the details are as follows.

First, the light shelf was designed with a folding structure to improve daylighting and generation performance, as shown in Figure 3. The light shelf was divided and modularized in a horizontal direction with the daylighting window to implement such a folding structure, and a hinge structure connected the divided light shelf modules. Second, 
reflectors and photovoltaic modules were installed alternately from the window side of the light shelf, which applies a folding technology and photovoltaic modules. As a result, folding the light shelf made the reflector angle symmetrical with the photovoltaic module angle (see Figure 3). This principle enables the proposed system to outperform conventional flat light shelves in terms of daylighting and generation. Third, the proposed system folds and unfolds the light shelf by moving along a rail, unlike previous methods in which the light shelf rotates around a rotating shaft.
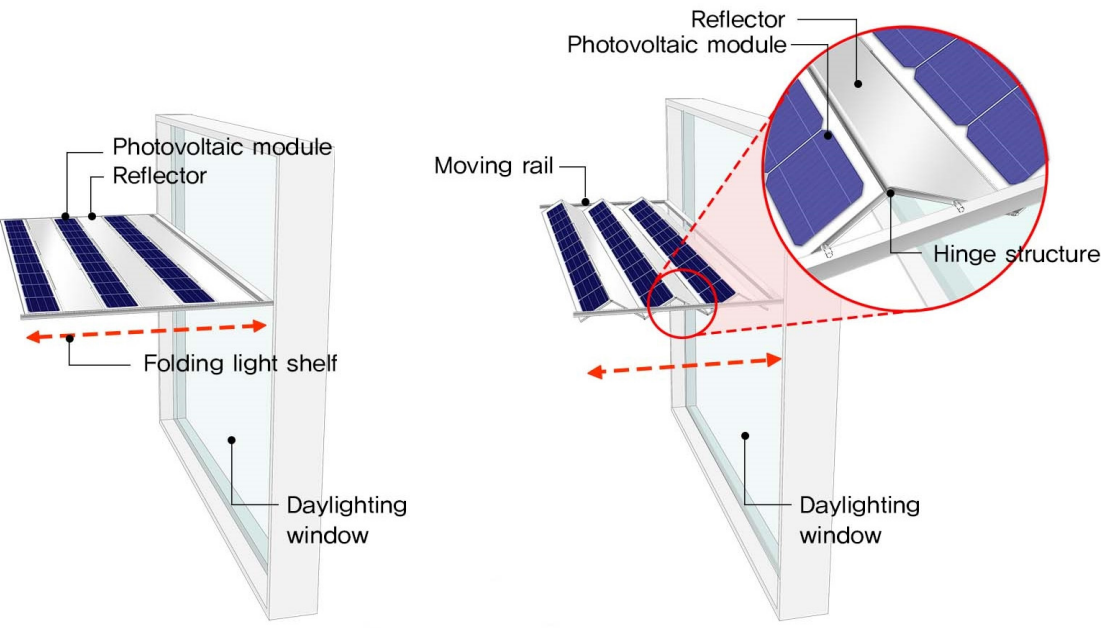

(a)

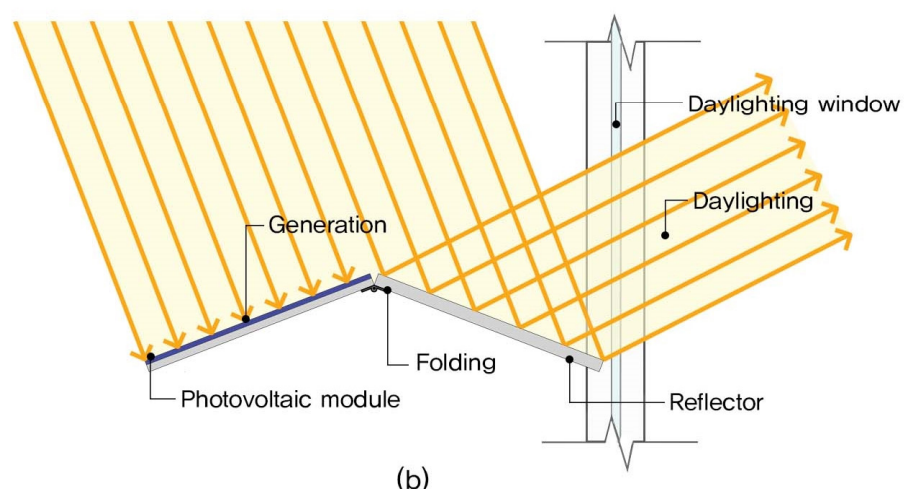

(b)

Figure 3. The concept and principle of the light shelf that applies folding technology and photovoltaic modules: (a) Structure of proposed system, (b) Daylighting and generation by the proposed system.

\subsection{Environment for Performance Evaluation}

A full-scale testbed including an artificial climate chamber was built to evaluate the performance of the proposed light shelf that applies folding technology and photovoltaic modules, and the details are as follows.

First, as shown in Figures 4 and 5, the dimensions of the internal space of the testbed were $4.9 \mathrm{~m} \times 6.6 \mathrm{~m} \times 2.5 \mathrm{~m}(\mathrm{~W} \times \mathrm{D} \times \mathrm{H})$. The reflectance of the floor, wall, and ceiling was set to $25 \%, 46 \%$, and $86 \%$, respectively. The window used to install the light shelf measured $1.9 \mathrm{~m} \times 1.7 \mathrm{~m}(\mathrm{~W} \times \mathrm{H})$ and was made of $24 \mathrm{~mm}$ thick pair glass with an 80 percent transmittance. Second, eight illuminance sensors were installed to measure the change in illuminance of the indoor space caused by the light shelf. Because of the height of the work surface, they were placed $0.85 \mathrm{~m}$ from the floor. Third, four lights were installed in the testbed using the IES 4-point method [35]. These LED lights were capable of 8-level dimming control (excluding lights off). Fourth, the testbed had an artificial climate chamber installed adjacent to the outside of the window. An artificial solar irradiation apparatus was installed in the chamber that would stimulate the brightness and altitude of the sun by regulating the intensity and angle of the natural light. The performance evaluation 
was carried out in an artificial environment due to its advantages in implementing a consistent external environment. The Grade-A artificial solar irradiation apparatus also ensured measurement uniformity following ASTM E927-85, resulting in valid results across performance evaluations. Due to mechanical limitations, this apparatus could not simulate the sun's azimuth. The temperature range of the artificial climate chamber was also adjustable in light of the findings of related works [25-27] that the generation efficiency of photovoltaic modules was significantly affected by temperature. Fifth, the current study develops an energy monitoring system to more precisely estimate lighting energy consumption (see Figure 4 for more detail).

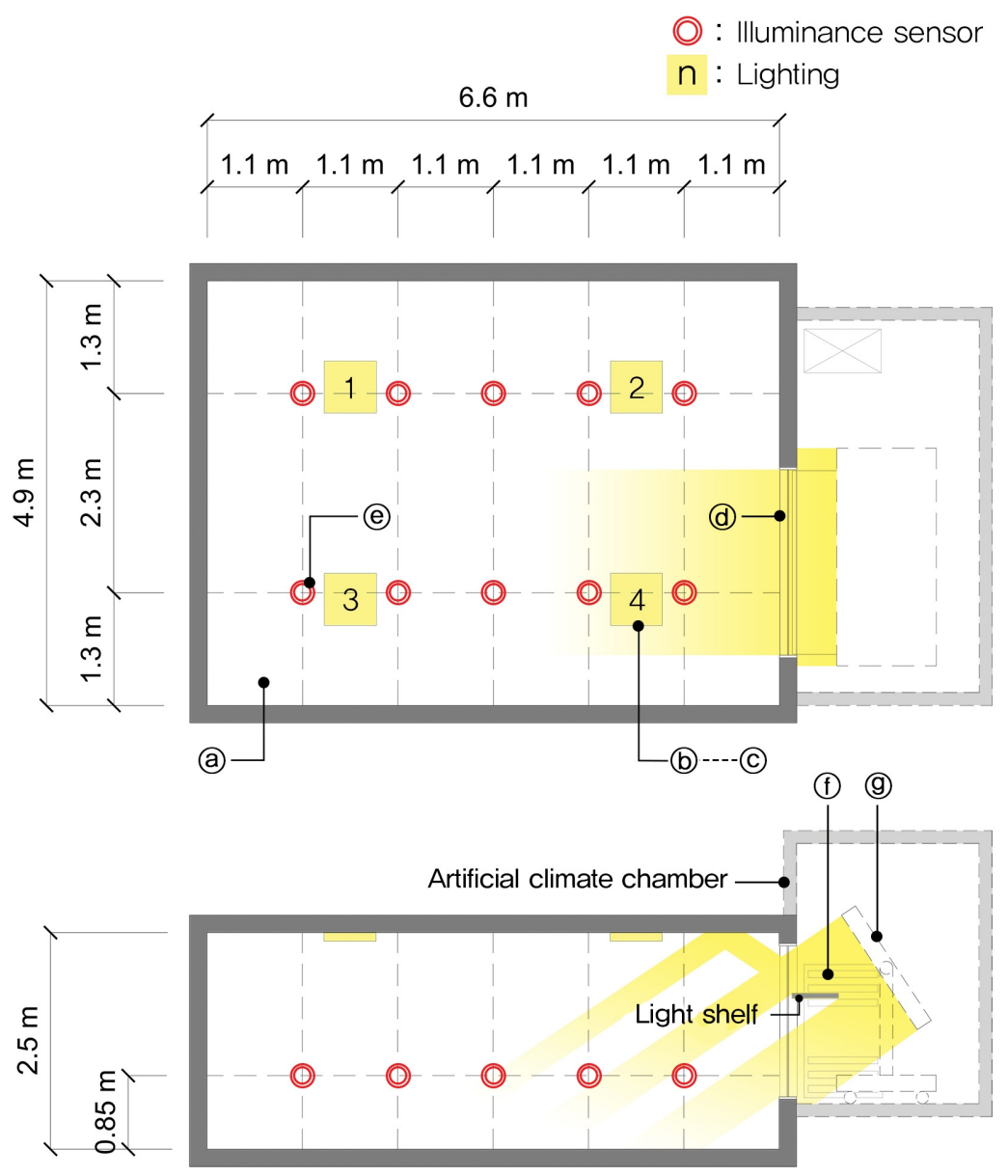

(a)Testbed

Size: $4.9 \mathrm{~m}(\mathrm{~W}) \times 6.6 \mathrm{~m}(\mathrm{D}) \times 2.5 \mathrm{~m}(\mathrm{H})$

Reflexibility: Ceiling ( $86 \%)$, Wall (46\%), Floor (25\%)

(b) Lighting

8 Level dimming (LED type) 4 ea

Dimension (mm): $600 \times 600$

Dimming Range: $10-100 \%$

(C) Energy monitoring

Model: SPM - 141

Measurement capacity: Single phase

$(220 \mathrm{~V}, 1-50 \mathrm{~A})$

Error rate: Within $2.0 \%$

Measurement items: power, voltage, current

(real - time, and accumulated amount)

(d) Daylight window
Size: $1.9 \mathrm{~m}(\mathrm{~W}) \times 1.7 \mathrm{~m}(\mathrm{H})$
Type: pair glass $24 \mathrm{~mm}(6 \mathrm{~mm}+12 \mathrm{~mm}+6 \mathrm{~mm})$
Transmissivity: $80 \%$
(e) Illuminance sensor
Sensing element: Silicon photo sensor, with filter
Detection range: 0 - $20,000 \mathrm{~lx}$
Precision: \pm 0.3
(1) Chamber thermostat
(9) Artificial solar irradiation apparatus
Light source with adjustable intensity
Light source with adjustable height / angle

Figure 4. The layout, cross-section, and equipment in the testbed for performance evaluation. 


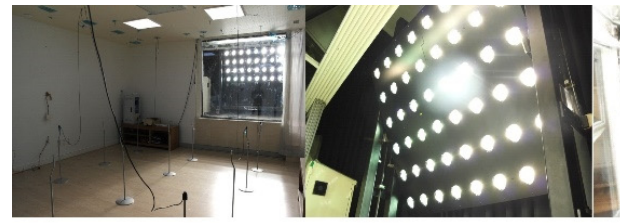

(a)

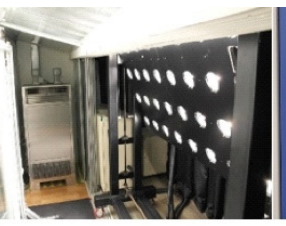

(c)

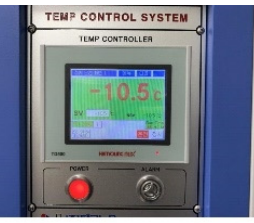

(d)

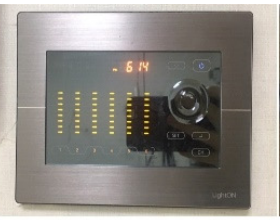

(e)

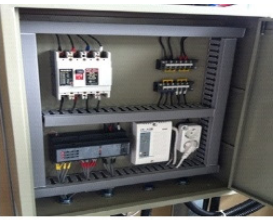

(f)

Figure 5. Environment for performance evaluation: (a) Testbed, (b) Artificial Solar Light Radiation Apparatus, (c) Chamber thermostat, (d) Chamber temperature controller, (e) Light dimming controller, (f) Energy monitoring system.

\subsection{Methods of Performance Appraisal}

The performance appraisal was conducted to prove the effectiveness of the daylighting and generation performance of the light shelf that applies folding technology and photovoltaic modules.

First, as shown in Table 3, this study set up three scenarios based on whether or not photovoltaic modules were used and how they worked. Case 1 was a standard light shelf that did not include a photovoltaic module. Case 2 was a light shelf with a photovoltaic module attached to the reflector, resulting in the photovoltaic module and reflector having the same angle. However, the area where the photovoltaic module was attached in Case 2 had the same size as the reflector where reflection occurs, considering the previous study findings [12], in which installing photovoltaic modules on the part of the light shelf reflector was found to provide advantages in terms of saving building energy by enabling daylighting and generation at the same time. As shown in Figure 1, a single rotating shaft was used to change the angles of the light shelves in Cases 1 and 2. In Case 2, the light shelf angle increased from $-70^{\circ}$ to $30^{\circ}$ in $10^{\circ}$ increments while considering the photovoltaic module's generation function. Case 3 was designed around a light shelf that employs folding technology as well as photovoltaic modules. As shown in Table 4, the light shelf is folded in stages. Each stage of folding changed the light shelf width, reflector angle, and photovoltaic module angle. The photovoltaic cells used in the photovoltaic module are specified in Table 5. Finally, as shown in Figure 6, this study used a profile to make the light shelf for a performance evaluation.

Table 3. Case settings for performance evaluation.

\begin{tabular}{|c|c|c|c|c|c|c|}
\hline \multirow[b]{2}{*}{ Case } & \multicolumn{2}{|c|}{ Light Shelf } & \multirow{2}{*}{$\begin{array}{c}\text { Photovoltaic Module } \\
\text { Application } \\
\text { (\# of Photovoltaic Cells } \\
\text { Applied) }\end{array}$} & \multirow{2}{*}{$\begin{array}{c}\text { Folding } \\
\text { Technology } \\
\text { Application }\end{array}$} & \multirow{2}{*}{$\begin{array}{l}\text { Operation } \\
\text { Method }\end{array}$} & \multirow{2}{*}{ Light Shelf Angle } \\
\hline & Width & Angle & & & & \\
\hline 1 & \multirow{3}{*}{$0.6 \mathrm{~m}$} & $\begin{array}{c}-10^{\circ}, 0^{\circ}, 10^{\circ}, \\
20^{\circ}, 30^{\circ}\end{array}$ & Not applied (0) & \multirow[b]{2}{*}{ Not applied } & \multirow[b]{2}{*}{$\begin{array}{l}\text { Rotation by a } \\
\text { rotating shaft }\end{array}$} & \\
\hline 2 & & $\begin{array}{l}-70^{\circ},-60^{\circ}, \\
-50^{\circ},-40^{\circ}, \\
-30^{\circ},-20^{\circ}, \\
-10^{\circ}, 0^{\circ}, 10^{\circ}, \\
20^{\circ}, 30^{\circ}\end{array}$ & Applied $\left(33^{*}\right)$ & & & \\
\hline 3 & & $0^{\circ}$ (fixed) & Applied $\left(33^{*}\right)$ & $\begin{array}{c}\text { Applied } \\
\text { (divided into } \\
6 \text { modules) }\end{array}$ & $\begin{array}{l}\text { Operates } \\
\text { along a rail } \\
\text { axis }\end{array}$ & \\
\hline
\end{tabular}

* The efficiency decreases at rate of $6.1 \%$ when the Photovoltaic module was applied using 33 photovoltaic cells. 
Table 4. Folding shape, light shelf angle, and photovoltaic module angle according to the width of Case 3.

\begin{tabular}{cccc}
\hline Folding Stage & $\begin{array}{c}\text { Light Shelf } \\
\text { Width (W) }\end{array}$ & $\begin{array}{c}\text { Reflector Module } \\
\text { Angle }(\alpha)\end{array}$ & $\begin{array}{c}\text { Photovoltaic } \\
\text { Module Angle ( } \beta \text { ) }\end{array}$ \\
\hline 1 (Straight, no folding) & $0.60 \mathrm{~m}$ & $0^{\circ}$ & $180^{\circ}$ \\
\hline 2 & $0.58 \mathrm{~m}$ & $14.8^{\circ}$ & $165.2^{\circ}$ \\
\hline 3 & $0.56 \mathrm{~m}$ & $21.0^{\circ}$ & $159^{\circ}$ \\
\hline 4 & $0.54 \mathrm{~m}$ & $25.8^{\circ}$ & $154.2^{\circ}$ \\
\hline 5 & $0.52 \mathrm{~m}$ & $29.9^{\circ}$ & $150.1^{\circ}$ \\
\hline 6 & $0.50 \mathrm{~m}$ & $33.6^{\circ}$ & $146.4^{\circ}$ \\
\hline & & & \\
\end{tabular}

Table 5. Photovoltaic cell specifications.

\begin{tabular}{cccc}
\hline Item & Specifications & Item & Specifications \\
\hline Max. Power & $2 \mathrm{~W}$ & Max. Current (Impp) & $670 \mathrm{~mA}$ \\
\hline Max. Voltage (Vmpp) & $3 \mathrm{~V}$ & Size & $165 \mathrm{~mm} \times 100 \mathrm{~mm}$ \\
\hline Efficiency & $16.3 \%$ & Reflectance & $1-6 \%$ \\
\hline
\end{tabular}

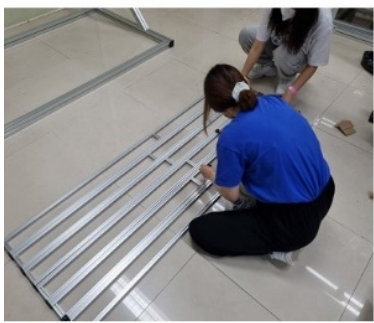

(1) Light shelf frame

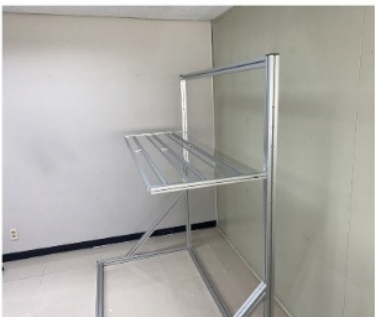

(2) Reflector module installation

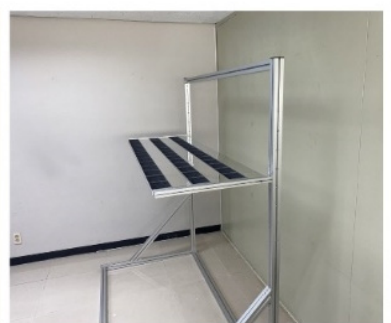

(3) Photovoltaic module installation

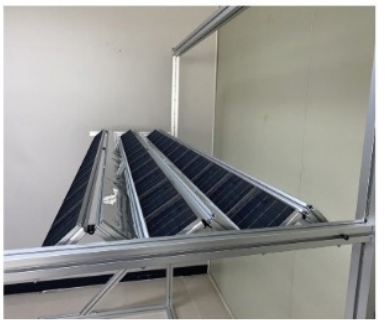

(4) Folding light shelf

Figure 6. Light shelf fabrication for performance evaluation.

Secondly, monitored the distribution of indoor illuminance according to the cases set for performance evaluation to derive the minimum illuminance, average illuminance, and uniformity ratio. The uniformity ratio was the ratio of the minimum illuminance to the average.

Thirdly, the study determined the dimming level and lighting energy consumption for each case to achieve optimal indoor illuminance, and the details are as follows. As shown in Figure 7, dimming control was only used when the minimum value measured by the eight illuminance sensors was less than $500 \mathrm{~lx}$. If the minimum value measured by the illuminance sensors was greater than $500 \mathrm{~lx}$, all lights were turned off without dimming control. The system monitored the values measured by the illuminance sensors while increasing the dimming levels sequentially from the light closest to the illuminance sensor with the minimum value. During this process, dimming control ended when all measurements by the illuminance sensors reached 500 lx. Finally, the performance of each 
case was compared by calculating the lighting energy consumption based on the level of dimming control.

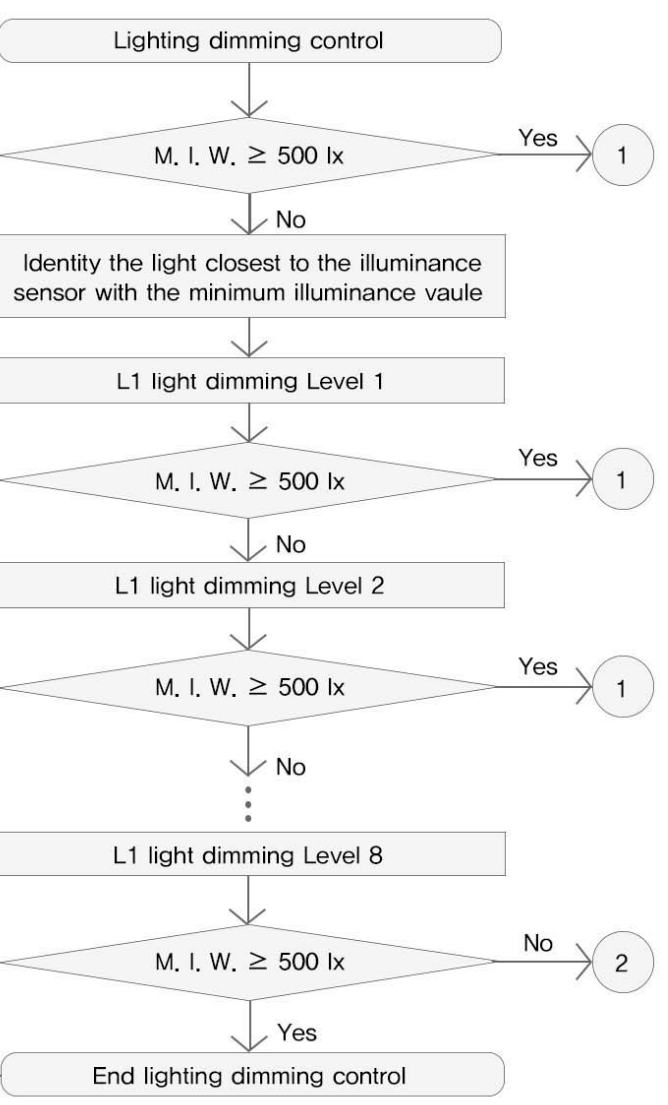

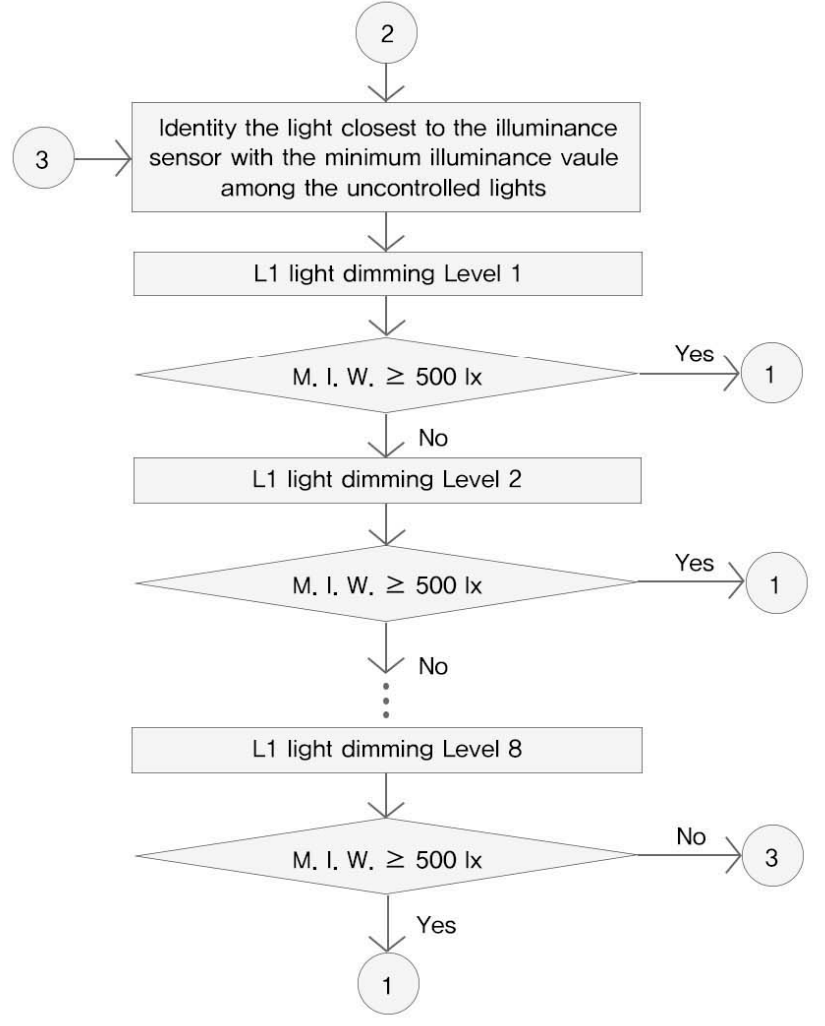

M. I. W. : Minimum illuminance walue of indoor illuminance sensors

Figure 7. Lighting dimming control flow chart for performance evaluation.

Fourth, the energy produced by the photovoltaic module's generation performance was measured in this study. The photovoltaic module's energy was calculated by multiplying the module's maximum voltage (Vmp) and maximum current (Imp) while producing power. Table 6 shows the specifications of the photovoltaic module used for performance evaluation and the equipment used to measure the voltage and current.

Table 6. Specifications of the voltage and current measuring device (Equipment name: MULLER 3201)

\begin{tabular}{ccc}
\hline Item & Specifications \\
\hline $\begin{array}{c}\text { Measurement item } \\
\text { (measurement capacity) }\end{array}$ & $\begin{array}{c}\text { DC Voltage }(0 \sim 600 \mathrm{~V}), \\
\text { DC Current }(0 \sim 60 \mathrm{~A})\end{array}$ \\
\hline Error rate & $\pm(0.5 \%+3)$ \\
\hline
\end{tabular}

Fifth, the artificial climate chamber of the testbed created the external environment of the outdoor space, where the performance evaluation was conducted for summer, midseason, and winter, as shown in Table 7. The experiment was performed under three external conditions based on seasonal variation (i.e., summer, middle season, and winter). More specifically, each condition was controlled hour by hour to reflect potential change in external illuminance and solar radiation during a $5 \mathrm{~h}$ session between $10 \mathrm{am}$ and $3 \mathrm{pm}$. The external environment's characteristics were specifically based on Seoul, Korea, which has four distinct seasons. The outdoor temperature for each season was determined by considering the Korea Meteorological Administration's average climate data for the past 
thirty years [38]. However, the solar irradiation for each season was determined by varying the intensity of the artificial solar irradiation apparatus rather than by observing actual climate data. This limitation was due to the performance evaluation being conducted in an artificial environment.

Table 7. Climatic settings for performance evaluation based on geographical specification.

\begin{tabular}{cccccccc}
\hline \multirow{2}{*}{ Season } & $\begin{array}{c}\text { Meridian } \\
\text { Altitude }\end{array}$ & \multicolumn{4}{c}{ External Illuminance (1x)/Solar Radiation (W/m $\left.{ }^{2}\right)$} & \multicolumn{2}{c}{ Outdoor } \\
\cline { 3 - 6 } & & $\mathbf{1 0 : 0 0 - 1 1 : 0 0}$ & $\mathbf{1 1 : 0 0 - 1 2 : 0 0}$ & $\mathbf{1 2 : 0 0 - 1 3 : 0 0}$ & $\mathbf{1 3 : 0 0 - 1 4 : 0 0}$ & $\mathbf{1 4 : 0 0 - 1 5 : 0 0}$ & Temperature \\
\hline Summer & 76.5 & $70,000 / 530$ & $80,000 / 638$ & $80,000 / 638$ & $80,000 / 638$ & $70,000 / 530$ & $27.1{ }^{\circ} \mathrm{C}$ \\
Middle & 52.5 & $50,000 / 414$ & $50,000 / 414$ & $60,000 / 476$ & $60,000 / 476$ & $50,000 / 414$ & $17.2{ }^{\circ} \mathrm{C}$ \\
season & 29.5 & $20,000 / 289$ & $30,000 / 332$ & $30,000 / 332$ & $30,000 / 332$ & $20,000 / 289$ & $-3.2^{\circ} \mathrm{C}$ \\
Winter & & & & &
\end{tabular}

Sixth, the optimal specifications (optimal angle and folding stage) were derived for each case. These were derived by considering lighting energy saving as a priority. When multiple specifications saved the same amount of energy, the one with the highest uniformity was deemed to be optimal. Conditions that would result in the glare as a result of introducing natural light directly into the room via the light shelf without bouncing it off the ceiling, on the other hand, were excluded from the optimal specifications.

\section{Results and Discussion}

\subsection{Performance Evaluation Results}

This study conducted a performance evaluation to validate the effectiveness of the light shelf that applies folding technology and photovoltaic modules. The results are as follows.

Firstly, Figure 8 illustrates the performance evaluation results of Case 1 (light shelf with no photovoltaic module), which shows that light shelf angle affects the daylighting performance. Increasing the light shelf angle during the summer was beneficial in saving lighting energy and improving the indoor uniformity ratio. Increasing the light shelf angle was also helpful during the middle season, but the uniformity ratio deteriorated when the light shelf angle was $30^{\circ}$. As shown in Figure 9, setting the angle at $30^{\circ}$ allows high illuminance light to reach a specific area only by reflecting off the light shelf, resulting in an illuminance imbalance in the indoor space. In winter, the increment in the light shelf angle was suitable for saving lighting energy by increasing the amount of natural light entering the room through light shelf reflection, but adjusting the light shelf angle to $30^{\circ}$ was inappropriate for saving lighting energy and improving the indoor uniformity ratio. This is because the solar altitude is lower in the summer compared to the winter and middle seasons, allowing natural light to enter deep into the indoor space through the daylighting window. Furthermore, during the winter, the solar altitude is $27.5^{\circ}$, so when the light shelf angle is $30^{\circ}$, the light shelf only acts as a shade, as shown in Figure 9 . A light shelf angle of $20^{\circ}$ was also excluded from the optimal specifications during the winter because, like using a $30^{\circ}$ angle during the middle season, it could reduce the uniformity ratio and cause glare. As a result, the optimal light shelf angles for Case 1 during the summer, mid-season, and winter were $30^{\circ}, 20^{\circ}$, and $10^{\circ}$, respectively, with lighting energy consumption of $0.471 \mathrm{kWh}, 0.309 \mathrm{kWh}$, and $0.134 \mathrm{kWh}$. 

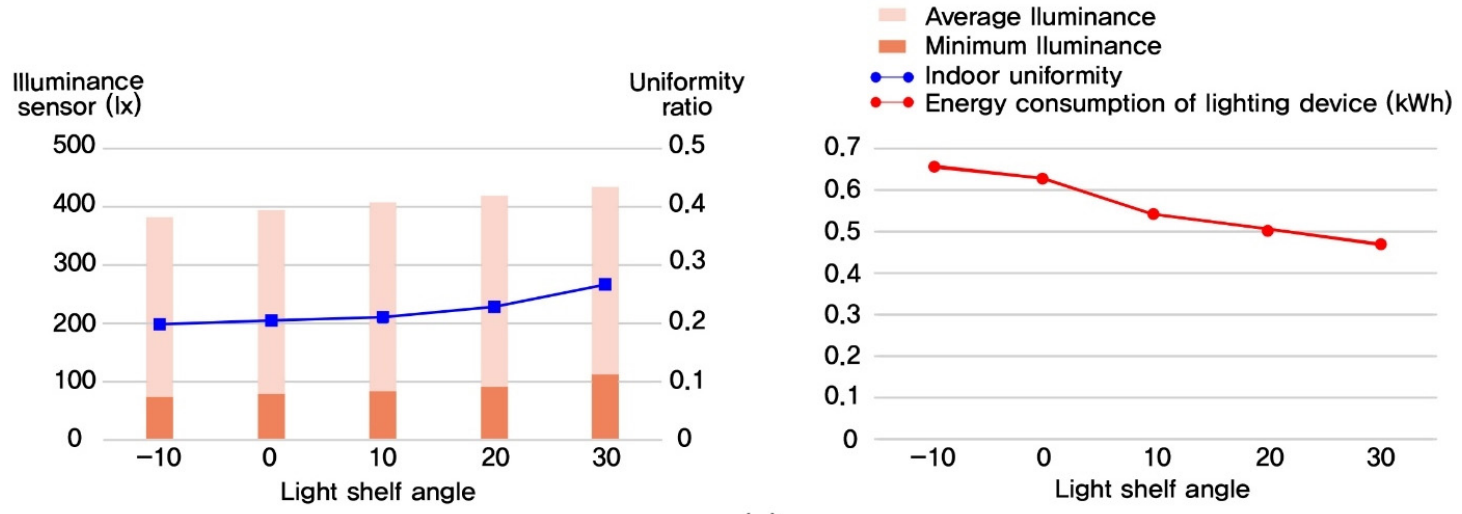

(a)
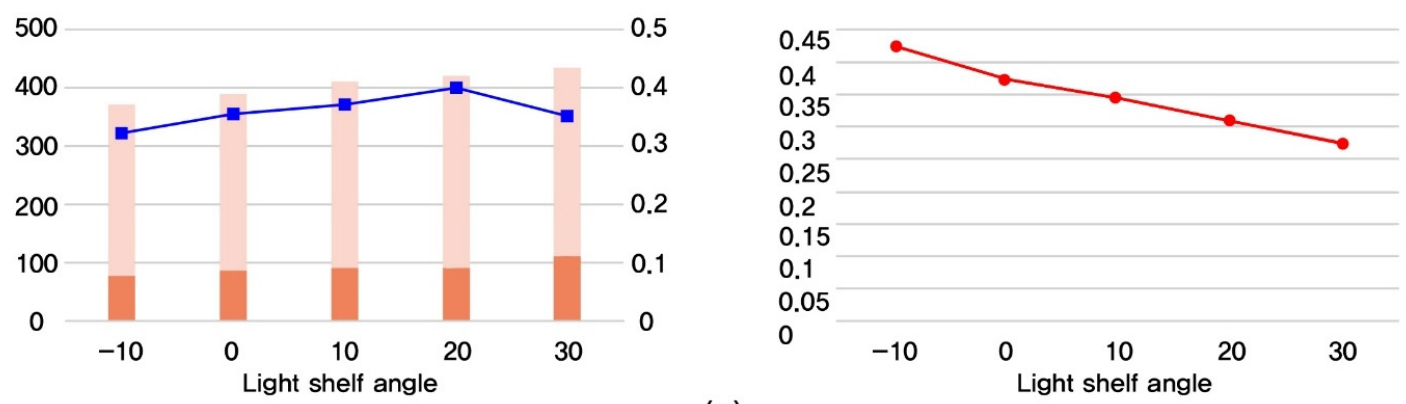

(b)
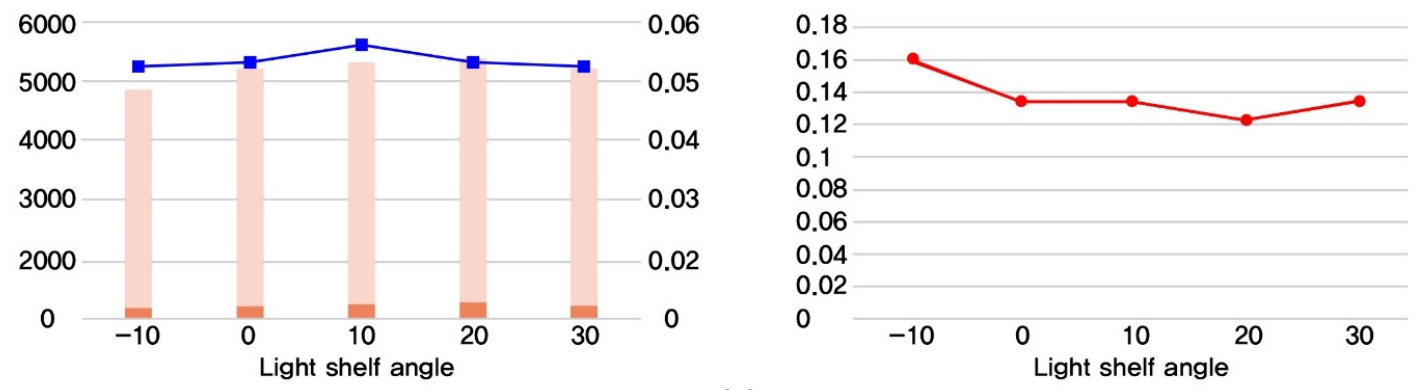

(c)

Figure 8. Indoor uniformity and lighting energy consumption according to the light shelf angle in Case 1: (a) Summer, (b) Middle season, (c) Winter.

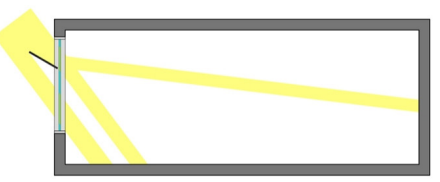

(a)

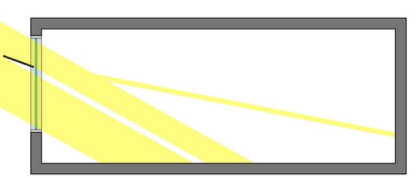

(b)

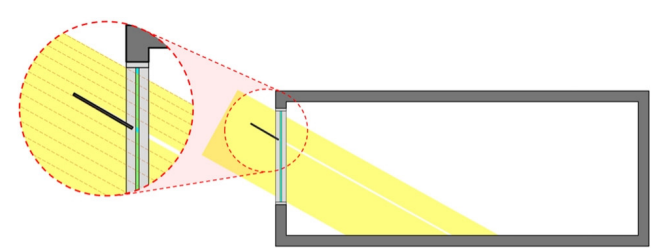

(c)

Figure 9. The inflow of natural light according to the light shelf angle in Case 1: (a) Middle season, Angle $30^{\circ}$, (b) Winter, Angle $20^{\circ}$, (c) Winter, Angle $30^{\circ}$.

Secondly, Figure 10 shows the output of a performance evaluation of Case 2 (light shelf applying photovoltaic module). In terms of saving lighting energy, the optimal specifications during summer, mid-season, and winter were $30^{\circ}, 20^{\circ}$, and $10^{\circ}$, respectively, the same as Case 1. However, in Case 2, the area of the reflector used for daylighting was reduced by $50 \%$ compared to Case 1 , reducing the amount of natural light entering the room through light shelf reflection and deteriorating uniformity, as shown in Figure 11. Case 2 
also has a higher lighting energy consumption than Case 1. Meanwhile, the photovoltaic module in Case 2 generated the most power at light shelf angles of $-10^{\circ},-40^{\circ}$, and $-60^{\circ}$, which proves that the closer the incident angle of natural light is to vertical, the higher the power generation efficiency. However, it is difficult to maximize both the daylighting and generation performance at the same time in Case 2 because it controls the reflector for daylighting and the photovoltaic module for concentrating light at the same angle. Therefore, the optimal specifications for Case 2 during summer, mid-season, and winter were $10^{\circ},-10^{\circ}$, and $20^{\circ}$, respectively, and the lighting energy consumption was $0.406 \mathrm{kWh}$, $0.314 \mathrm{kWh}$, and $0.100 \mathrm{kWh}$, respectively.

$\longrightarrow$ : Energy consumption of lighting device

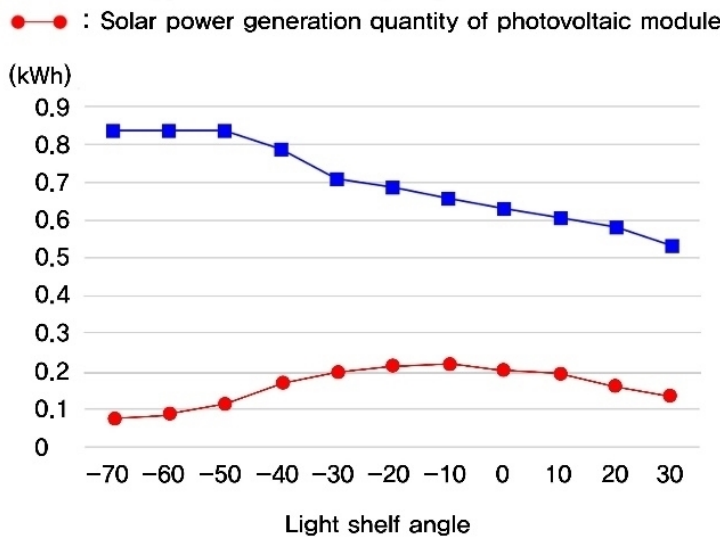

(a)

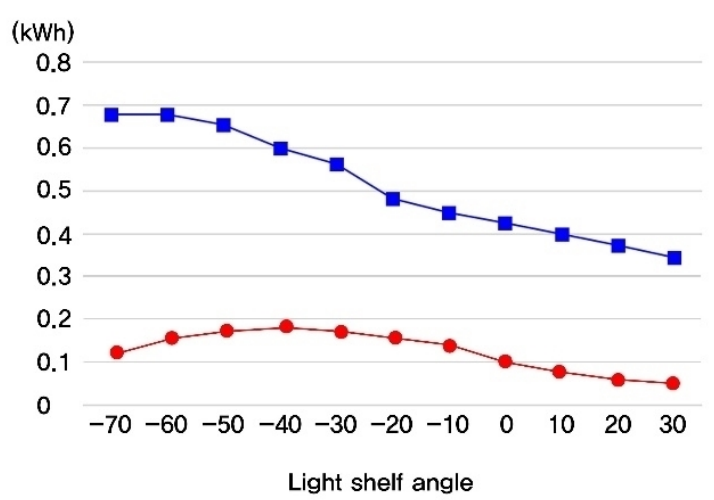

(b)

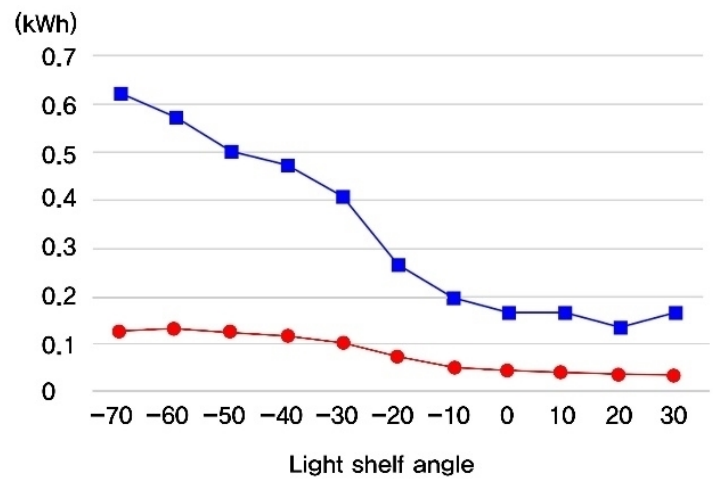

(c)

Figure 10. Lighting energy consumption and the power generated by the photovoltaic module according to the light shelf angle in Case 2: (a) Summer, (b) Mid-season, (c) Winter. 


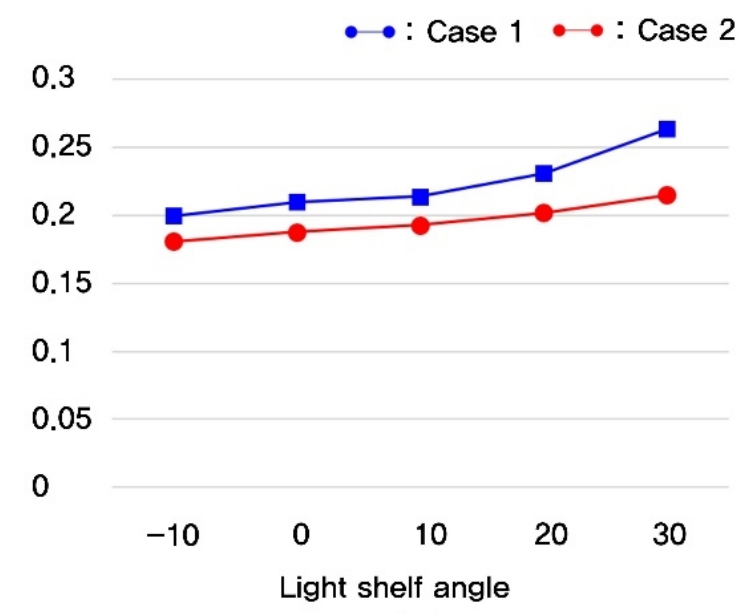

(a)

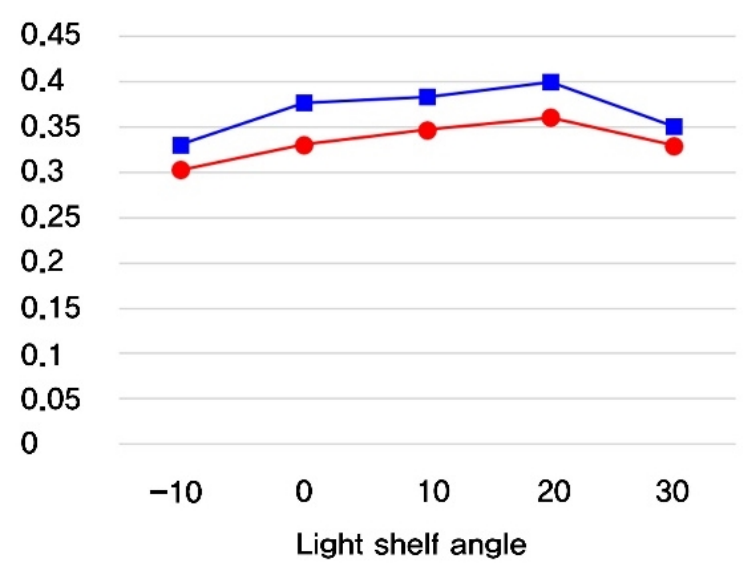

(b)

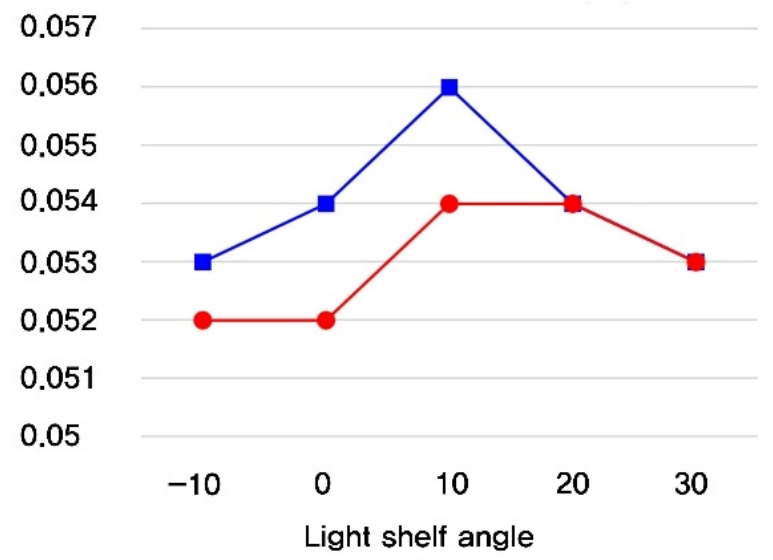

(c)

Figure 11. Case 1 and Case 2 indoor uniformity analysis: (a) Summer, (b) Mid-season, (c) Winter.

Thirdly, Figure 12 shows the results of a performance appraisal of Case 3 (light shelf applying folding technology and photovoltaic module). The optimal specifications for Case 3, considering only lighting energy savings and improving indoor light uniformity during summer, mid-season, and winter were folding stages 6,4 , and 3(4), respectively. During the winter, however, as shown in Table 4, folding stages 3 and 4 reduce the light shelf angle to $21^{\circ}$ and $25.8^{\circ}$, respectively. These angles, like a light shelf angle of $20^{\circ}$ in the winter, cause glare by allowing the direct flow of natural light into the interior space 
by reflecting off the light shelf, so they were excluded from the optimal specifications. Taking these factors into account, the best specifications for saving lighting energy and improving indoor uniformity in Case 3 were folding stages 6, 4, and 2 for summer, midseason, and winter, respectively. The optimal specifications for generating power by the photovoltaic module in Case 3 were folding stages 3, 6, and 6 for summer, mid-season, and winter, respectively. Therefore, the optimal specifications for Case 3 during summer, mid-season, and winter were folding stages 6, 4, and 4, respectively, and the lighting energy consumption was $0.307 \mathrm{kWh}, 0.224 \mathrm{kWh}$, and $0.034 \mathrm{kWh}$, respectively.

$\longrightarrow$ : Energy consumption of lighting device

$\longrightarrow$ : Solar power generation quantity of solar module

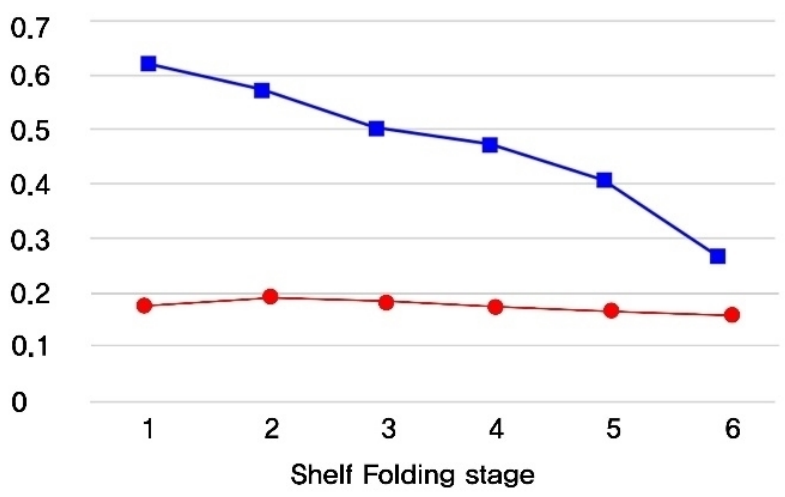

(a)

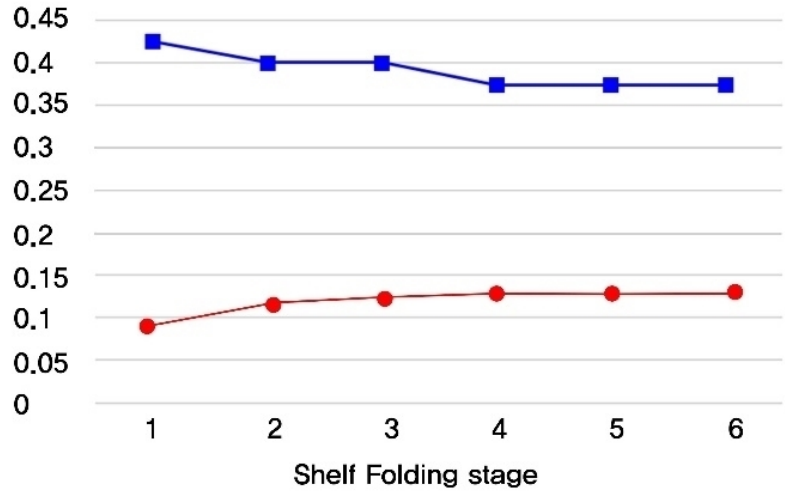

(b)

\subsection{5}

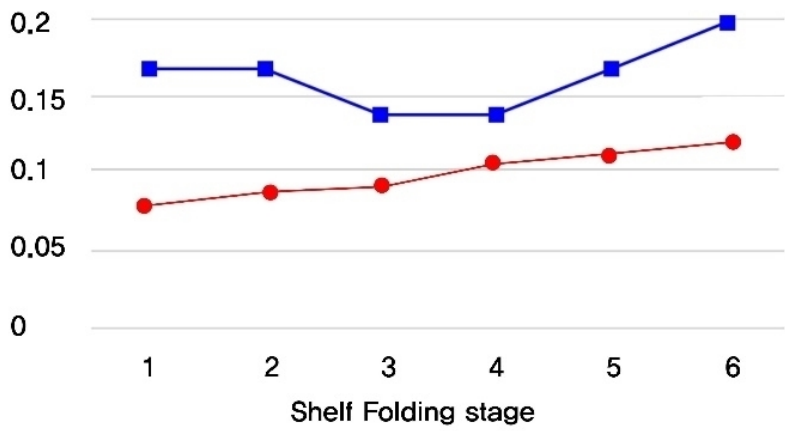

(c)

Figure 12. Lighting energy consumption and the power generated by the photovoltaic module according to the folding stage in Case 3: (a) Summer, (b) Mid-season, (c) Winter. 


\subsection{Performance Evaluation Discussion}

This study proposed a folding technology to improve light shelves' daylighting and generation efficiency that incorporates photovoltaic modules and validated its effectiveness through a performance evaluation. A discussion of the results follows.

First, the optimal specifications for Cases 1,2, and 3 were derived through evaluating their performance. Figure 13 shows the energy consumption based on these results. Case 2 reduced energy consumption by $10.3 \%$ compared to Case 1, demonstrating the effectiveness of the photovoltaic module used on light shelves. Case 3 reduced energy consumption by $31.3 \%$ compared to Case 2, due to improved daylighting and generation efficiency achieved by adjusting the reflector and photovoltaic module angles through folding. In particular, although the proposed light shelf that applies folding technology and photovoltaic modules (Case 3) had an operating range of only $0.1 \mathrm{~m}$, it reduced building energy by a significant amount compared to the conventional light shelf. These results prove the effectiveness of the proposed system (Case 3).

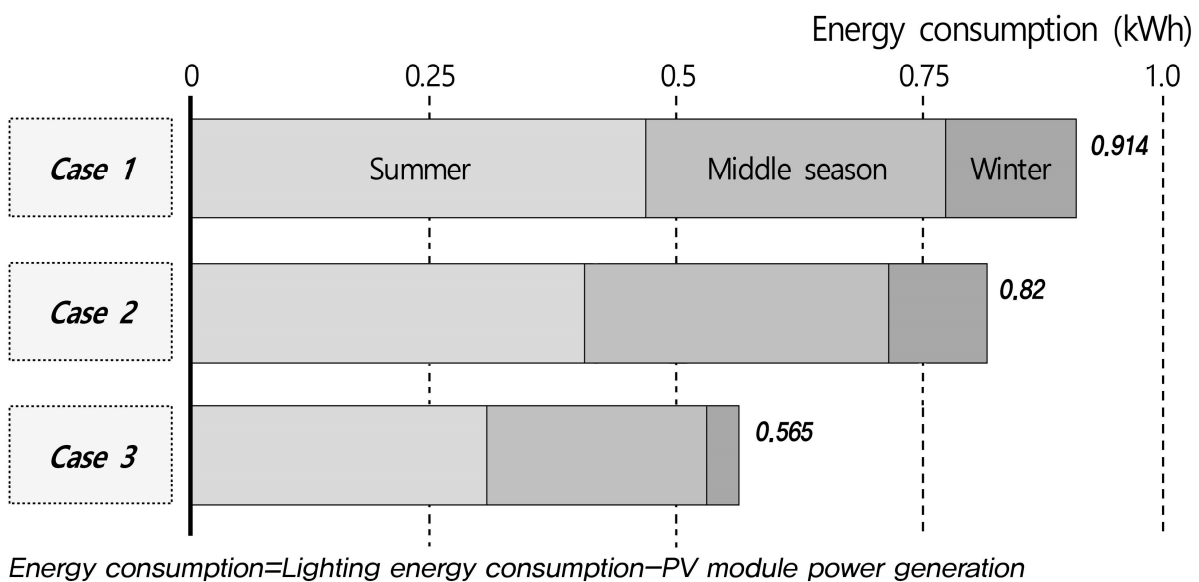

Figure 13. Energy consumption analysis (by Case).

Second, Case 3 uses folding technology to cope with external wind pressure and snow load by completely folding the light shelf. For example, if you are concerned about the damage caused by wind pressure exceeding a certain level, you can fold the light shelf to avoid any damage caused by protruding outside. Case 3 , in particular, connects each module with a hinge structure, resulting in gaps between each module. Compared to conventional movable light shelves, this structural feature responds quickly to external environmental factors such as wind pressure.

Third, installing photovoltaic modules on light shelves reduces the area occupied by reflectors to perform daylighting, which reduces the amount of natural light flowing indoors through light shelf reflection. In this context, the light shelf with a photovoltaic module may cause issues, such as increasing the amount of lighting energy required to maintain optimal indoor illuminance and reducing indoor uniformity. Therefore, further research should be conducted on adjusting the width of the light shelf according to the area occupied by the photovoltaic module in the light shelf.

\section{Conclusions}

A folding technology was proposed to improve the daylighting and generation performance of light shelves that apply photovoltaic modules, and its performance was evaluated through a full-scale testbed. The main findings are as follows.

First, the proposed light shelf that employs folding technology and photovoltaic modules has a structure in which reflectors and photovoltaic modules are installed alternately by modularizing the light shelf. A hinge structure connects each module, allowing the system to be folded. This structure enables the reflector module and photovoltaic module to be symmetrical and operate at different angles depending on the degree of folding. Due to 
such structural features, the proposed light shelf that applies folding technology and photovoltaic modules can improve both daylighting and generation efficiency. This system also employs a novel operation method based on rails instead of conventional light shelves, which control the light shelf angle via a rotating shaft.

Second, the optimal light shelf angle for each case was derived. The optimal light shelf angles were based on the lighting energy consumption and uniformity ratio to maintain the optimal indoor illuminance. Angles that may cause glare were excluded, even if they were excellent in terms of saving energy. The optimal angles for a light shelf without a photovoltaic module during the summer, mid-season, and winter were $30^{\circ}, 20^{\circ}$, and $10^{\circ}$, respectively, indicating that the angles must be controlled by operating or moving the light shelf to improve performance. In contrast, the optimal angles for a light shelf with a photovoltaic module during the summer, mid-season, and winter were $10^{\circ},-10^{\circ}$, and $20^{\circ}$, respectively, compared to a light shelf without a photovoltaic module. The photovoltaic module and light reflector module require different angles to increase power generation efficiency and daylighting efficiency.

Third, the light shelf that applies folding technology and photovoltaic modules can reduce energy consumption by $38.2 \%$ and $31.3 \%$, respectively, compared to light shelves with no photovoltaic modules and light shelves with photovoltaic modules but no folding technology. These results validate the effectiveness of the application of photovoltaic modules to light shelves and prove that the folding technology can improve both daylighting and generation efficiency.

Fourth, the light shelf that applies a photovoltaic module was unsuitable in terms of improving the indoor uniformity compared to the light shelf with no photovoltaic module because the area occupied by the reflector decreases due to installing the photovoltaic module, which leads to reducing the amount of natural light flowing into the room through the light shelf. This aspect should be considered when designing light shelves that apply photovoltaic modules.

This study is significant because it proposes and validates a new technology related to light shelves to save building energy, a primary current concern. However, due to the use of a testbed, the performance evaluation was carried out in a restricted external environment. Other limitations include the fact that various other light shelf variables, such as width and height, were not considered. As a result, additional in-depth studies should be conducted in further research in this sector.

Author Contributions: Methodology, H.L.; writing—original draft preparation, H.L. and S.H.; visualization, S.H.; writing—review and editing, H.L. and J.S.; supervision, J.S. All authors have read and agreed to the published version of the manuscript.

Funding: This work was supported by the National Research Foundation of Korea (NRF) grant funded by the Korea government (MSIT) (NRF-2020R1C1C1004704) (NRF-2021R1A2B5B02001469).

Institutional Review Board Statement: Not applicable.

Informed Consent Statement: Not applicable.

Data Availability Statement: No additional data available.

Acknowledgments: None stated.

Conflicts of Interest: The authors declare no conflict of interest.

\section{References}

1. Heng, C.Y.S.; Lim, Y.W.; Ossen, D.R. Horizontal light pipe transporter for deep plan high-rise office daylighting in tropical climate. Build. Environ. 2020, 171, 106645. [CrossRef]

2. Jenkins, D.; Muneer, T. Modelling light-pipe performances-A natural daylighting solution. Build. Environ. 2003, 38, 965-972. [CrossRef]

3. Lee, H.; Jang, H.; Seo, J. A preliminary study on the performance of an awning system with a built-in light shelf. Build. Environ. 2018, 131, 255-263. [CrossRef] 
4. Mandalaki, M.; Papantoniou, S.; Tsoutsos, T. Assessment of energy production from photovoltaic modules integrated in typical shading devices. Sustain. Cities Soc. 2014, 10, 222-231. [CrossRef]

5. Hashemi, A. Daylighting and solar shading performances of an innovative automated reflective louvre system. Energy Build. 2014, 82, 607-620. [CrossRef]

6. Brzezicki, M. An Evaluation of Useful Daylight Illuminance in an Office Room with a Light Shelf and Translucent Ceiling at $51^{\circ}$ N. Buildings 2021, 11, 494. [CrossRef]

7. Moazzeni, M.H.; Ghiabaklou, Z. Investigating the influence of light shelf geometry parameters on daylight performance and visual comfort, a case study of educational space in Tehran, Iran. Buildings 2016, 6, 26. [CrossRef]

8. Lim, Y.W.; Heng, C.Y.S. Dynamic internal light shelf for tropical daylighting in high-rise office buildings. Build. Environ. 2016, 106, 155-166. [CrossRef]

9. Lee, H.; Kim, K.; Seo, J.; Kim, Y. Effectiveness of a perforated light shelf for energy saving. Energy Build 2017, 144, 144-151. [CrossRef]

10. Kim, K.; Lee, H.; Jang, H.; Park, C.; Choi, C. Energy-saving performance of light shelves under the application of user-awareness technology and light-dimming control. Sustain. Cities Soc. 2019, 44, 582-596. [CrossRef]

11. Hwang, T.; Kim, J.T.; Chung, Y. Power performance of photovoltaic-integrated lightshelf systems. Indoor Built Environ. 2014, 23, 180-188. [CrossRef]

12. Lee, H. Performance evaluation of a light shelf with a solar module based on the solar module attachment area. Build. Environ. 2019, 159, 106161. [CrossRef]

13. Claros, S.; Soler, A. Indoor daylight climate-influence of light shelf and model reflectance on light shelf performance in Madrid for hours with unit sunshine fraction. Build. Environ. 2002, 37, 587-598. [CrossRef]

14. Warrier, G.; Raphael, B. Performance evaluation of light shelves. Energy Build 2017, 140, 19-27. [CrossRef]

15. Lee, H.; Seo, J.; Kim, S. Improvement of light-shelf performance through the use of a diffusion sheet. Build. Environ. 2018, 144, 248-258. [CrossRef]

16. Lee, H.; Seo, J. Performance evaluation of external light shelves by applying a prism sheet. Energies 2020, 13, 4618. [CrossRef]

17. Mangkuto, R.A.; Feradi, F.; Putra, R.E.; Atmodipoero, R.T.; Favero, F. Optimisation of daylight admission based on modifications of light shelf design parameters. J. Build. Eng. 2018, 18, 195-209. [CrossRef]

18. Lee, H.; Seo, J.; Choi, C. Preliminary study on the performance evaluation of a light shelf based on reflector curvature. Energies 2019, 12, 4295. [CrossRef]

19. Meresi, A. Evaluating daylight performance of light shelves combined with external blinds in south-facing classrooms in Athens, Greece. Energy Build. 2016, 116, 190-205. [CrossRef]

20. Lee, H. A Basic Study on the Performance Evaluation of a Movable Light Shelf with a Rolling Reflector That Can Change Reflectivity to Improve the Visual Environment. Int. J. Environ. Res. Public Health 2020, 17, 8338. [CrossRef]

21. Ebrahimi-Moghadam, A.; Ildarabadi, P.; Aliakbari, K.; Fadaee, F. Sensitivity analysis and multi-objective optimization of energy consumption and thermal comfort by using interior light shelves in residential buildings. Renew. Energy 2020, 159, 736-755. [CrossRef]

22. Lee, H.; Gim, S.; Seo, J.; Kim, Y. Study on movable light-shelf system with location-awareness technology for lighting energy saving. Indoor Built Environ. 2016, 26, 796-812. [CrossRef]

23. Majd, A.E.; Ekere, N.N. Crack initiation and growth in photovoltaic module interconnection. Sol. Energy 2020, 206, 499-507. [CrossRef]

24. Jung, T.H.; Song, H.E.; Ahn, H.K.; Kang, G.H. A mathematical model for cell-to-module conversion considering mismatching solar cells and the resistance of the interconnection ribbon. Sol. Energy 2014, 103, 253-262. [CrossRef]

25. Reddy Penaka, S.; Kumar Saini, P.; Zhang, X.; Amo, A.D. Digital Mapping of Techno-Economic Performance of a Water-Based Solar Photovoltaic/Thermal (PVT) System for Buildings over Large Geographical Cities. Buildings 2020, 10, 148. [CrossRef]

26. Mattei, M.; Notton, G.; Cristofari, C.; Muselli, M.; Poggi, P. Calculation of the polycrystalline photovoltaic module temperature using a simple method of energy balance. Renew. Energy 2006, 31, 553-567. [CrossRef]

27. Elbakheit, A.R. A Ducted Photovoltaic Façade Unit with Buoyancy Cooling: Part I Experiment. Buildings 2019, 9, 88. [CrossRef]

28. Zaite, A.; Belouaggadia, N.; Cherifa, A.; Ezzine, M. Performance improvement of photovoltaic cells using night radiative cooling technology in a PV/T collector. J. Build. Eng. 2021, 42, 102843. [CrossRef]

29. Mahdi, A.H.; Aljubury, I.M.A. Experimental investigation of two-stage evaporative cooler powered by photovoltaic panels using underground water. J. Build. Eng. 2021, 44, 102679. [CrossRef]

30. Elbakheit, A.R. A Ducted Photovoltaic Façade Unit with Buoyancy Cooling: Part II CFD Simulation. Buildings 2019, 9, 133. [CrossRef]

31. Marion, B. Numerical method for angle-of-incidence correction factors for diffuse radiation incident photovoltaic modules. Sol. Energy 2017, 147, 344-348. [CrossRef]

32. Bora, B.; Kumar, R.; Sastry, O.S.; Prasad, B.; Mondal, S.; Tripathi, A.K. Energy rating estimation of photovoltaic module technologies for different climatic conditions. Sol. Energy 2018, 174, 901-911. [CrossRef]

33. Barman, S.; Chowdhury, A.; Mathur, S.; Mathur, J. Assessment of the efficiency of window integrated CdTe based semi-transparent photovoltaic module. Sustain. Cities Soc. 2018, 37, 250-262. [CrossRef] 
34. Meerbeek, B.W.; de Bakker, C.; de Kort, Y.A.; van Loenen, E.J.; Bergman, T. Automated blinds with light feedback to increase occupant satisfaction and energy saving. Build. Environ. 2016, 103, 70-85. [CrossRef]

35. Illuminating Engineering Society. The Lighting Handbook, 10th ed.; Illuminating Engineering Society (IES): New York, NY, USA, 2011.

36. KSA 3011-2013; Recommended Levels of Illumination. The Korean Standards Association (KSA): Seoul, Korea, 1998.

37. ISZ 9110: 2010; Recommended Levels of Illumination. Japanese Industrial Standards Committee: Tokyo, Japan, 2010.

38. Korea Meteorological Administration, Climate Information. Available online: http://www.kma.go.kr/eng/weather/climate/ worldclimate.jsp (accessed on 16 November 2021). 